\title{
Detecting changes in tree health and productivity of silver fir in Slovenia
}

\author{
By N. Torelli ${ }^{1}$, W. C. Shortle ${ }^{3}$, K. Cufar ${ }^{1}$, F. Ferlin ${ }^{2}$ and K. T. Smith ${ }^{3}$ \\ ${ }^{1}$ Biotechnical Faculty, Department of Wood Science and Technology, University of Ljubljana, p.p. 95, \\ Rozna dolina, Cesta VIII/34, 1111 Ljubljana, Slovenia; ${ }^{2}$ Slovenian Forestry Institute, Vecna Pot 2, 1000 \\ Ljubljana, Slovenia; ${ }^{3}$ North-eastern Research Station, U.S. Department of Agriculture, Forest Service, \\ PO Box 640, Durham, New Hampshire 03824, USA (for correspondence)
}

\section{Summary}

Cambial electrical resistance (CER) was used as an objective measure of vitality of silver fir (Abies alba) in the forests of Slovenia. Trees were rated during the growing season by CER and a subjective crown status index (CSI). Both CER and CSI were inversely correlated to annual ring width increment. Using both CER and CSI, fir were assigned to vitality and vigour categories. Inferences made from these categories and radial growth trends indicated that ring growth decreased prior to the development of canopy symptoms. This decrease in ring growth would have been detected as an increase in CER. This pattern of decline is consistent with the decline of trees due to chronic below-ground stress. Variation in CER was due both to the vascular cambium and to the thickness of the nonconducting phloem.

\section{Introduction}

Mature silver fir (Abies alba Mill.) in the forests of Slovenia have sustained high mortality in recent decades (Solar 1986). The precise aetiology of declining tree health is not known, but air pollution combined with drought, or other climatic changes, is considered to be part of the problem. Narrow annual rings in dead and dying fir indicated that wood formation by the vascular cambium had been suppressed for several decades, well before crown symptoms of decline became obvious (TORELli et al. 1986; Levanic 1997). This same relationship has been observed in silver fir in France (BECKer et al. 1995) and Germany (SHORTLE and BAUCH 1986). Early detection of reduced cambial activity and wood formation, prior to needle death and crown dieback, would help forest managers evaluate future risks of mortality. Early detection of increased cambial mitosis and wood formation would also help forest managers evaluate remedial activities taken to reduce the problem of decline in threatened stands.

In several species of conifers and broadleaf trees, cambial electrical resistance (CER) measured during the growing season was related to radial growth (SHORTLE et al. 1977, 1979; Davis et al. 1980; Blanchard et al. 1983; Shortle 1985; Lindberg and Johansson 1989; OstrofsKy and SHORTLE 1989). The relationship of CER to ring width in balsam fir (Abies balsamea L.) was linked to the thickness of the vascular cambial zone (VCZ) during the growing season (BLANCHARD et al. 1983; SMITH et al. 1984). In that research on balsam fir, the VCZ was defined as the vascular cambium and undifferentiated derivatives on both sides of the vascular cambium. The low CER of high vitality trees was attributed to comparatively greater numbers of undifferentiated cambial derivatives per radial file of the

Received 1.11.1997; accepted: 3.8.1998; edited by C. Delatour 
VCZ (SMiTH et al. 1984). In this current research, the VCZ is operationally defined as the cambial initials, undifferentiated and immature cambial derivatives, and conducting phloem (Oven 1993; Oven et al. 1995).

The current research has three objectives: to determine the relationship of CER to annual ring width of mature silver fir declining forest stands in Slovenia; to determine how past changes in ring width may have been detectable by periodic measurements of CER; and to determine whether the thickness of the living bark affects CER.

\section{Materials and methods}

\subsection{Study areas}

Silver fir were measured at Bistra and Ravnik, two areas that are representative of the silver fir-beech forest of Slovenia between Ljubljana and Trieste. The forest canopies at both areas are dominated by silver fir. Both areas contain rendzina and brown soils on limestone and dolomite parent material. Bistra (elev. $450-600 \mathrm{~m}, 116$ trees) is a mixed forest stand of silver fir, beech, spruce, and maple. Bistra is managed for frequent, heavy cutting due to a severe decline problem. Ravnik (elev. $500-700 \mathrm{~m}, 269$ trees sampled) is a mixed forest stand of silver fir, beech, maple, and elm. Ravnik is managed by a group selection system and has experienced less severe decline than Bistra. Fir sampled at both locations had common characteristics and were treated as a single population.

\subsection{Tree selection}

Measured fir were dominant or codominant in the forest canopy with a mean diameter at $1.4 \mathrm{~m}$ above ground of $53.7 \mathrm{~cm}$ and a standard error of 0.7 . Tree diameters were normally distributed (skewness $=0.318$, kurtosis $=-0.195$ ). Smaller trees or those with crowns beneath the canopy were avoided due to a naturally higher CER during the growing season. Also not included were over-mature fir in advanced stages of crown death. Severely diseased fir may contain internal infections that extend into the vascular cambium zone, producing pathologically low CER values (Fig. 1A).

\subsection{Crown ratings}

Selected fir were rated late in the growing season of 1988 according to a seven class crown status index (CSI) system based on progressive needle loss and necrosis (modified from BOSSHARD 1986). In summary, a class 1 tree had a full, dense green crown; a class 4 tree had a thin crown with perhaps some evidence of chlorosis, but no marked browning of the needles; a class 5 tree had browning of needles as well as a thin crown; a class 7 tree was severely diseased but retained some green needles. Class 1-4 fir were considered relatively healthy, but had progressively more transparent crowns due to progressive chlorosis of the foliage, as well as the shedding of older needles. Class 5-7 were diseased as indicated by progressive needle discoloration, necrosis, and defoliation.

\subsection{Measurement of CER and ring width}

CER was measured in thousands of ohms ( $\mathrm{k}$ ) during the first week of August 1989. Measurements were made with a Conditiometer (Bollmann Elektronik-Systeme, Rielasingen, 

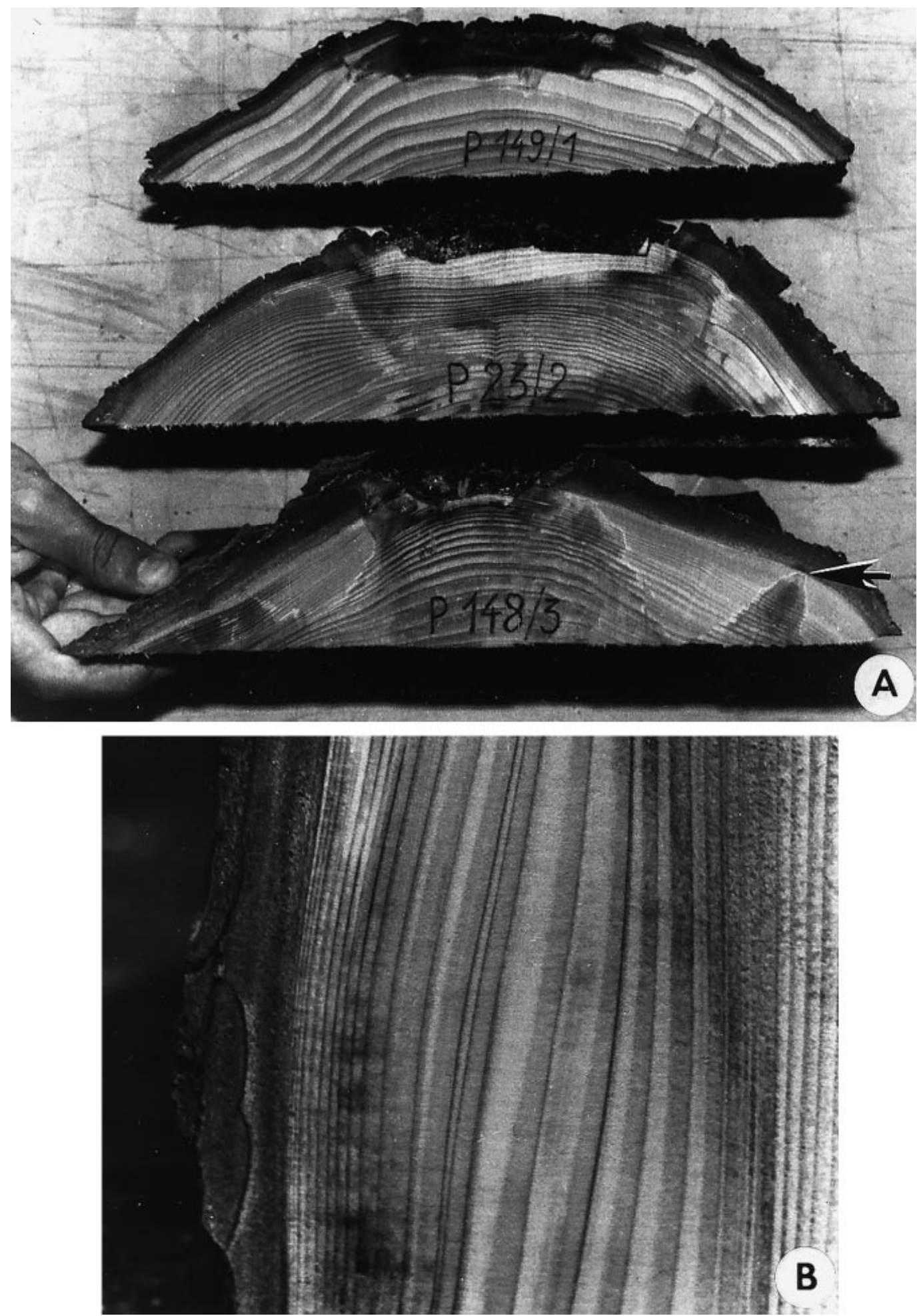

Fig. 1. A: arrow indicates spread of internal infection into vascular cambial zone. B: variation in thickness of live inner bark (nonconducting phloem) due to periderm formation

Germany). The Conditiometer operates similarly to the Shigometer (Osmose Wood Preserving Co., Buffalo, New York, USA) in a somewhat higher range of resistance values. The meter was fitted with a No. 2E Delmhorst moisture detector electrode with dual $54 \mathrm{~mm}$ 
stainless steel contact pins in a no. 552/A-106 retainer; pin separation was $11 \mathrm{~mm}$ (Delmhorst Instrument Co., Towaco, NJ, USA). In a vertical alignment, electrode pins were pushed through the rhytidome, nonconducting phloem, the vascular cambial zone (including the conducting phloem), and into the outer sapwood at $1.3 \mathrm{~m}$ above ground. The CER was recorded after the meter had stabilized.

Following the 1989 growing seaon, small wedges of bark and wood were cut at $1.3 \mathrm{~m}$ above the ground from stems previous measured for CER. From the flat transverse surface of each wedge, the width of the outermost annual ring $\left(\mathrm{RW}_{1989}\right)$ was measured to the nearest $0.1 \mathrm{~mm}$.

The relationship of the subjective CSI to $\mathrm{RW}_{1989}$ was determined using the Spearman rank correlation test. The relationship of objective CER to $\mathrm{RW}_{1989}$ was determined by the Spearman test and by linear regression analysis.

The wood-forming capacity or vitality of sampled fir was categorized by CER: high vitality, CER $\leqslant 10.5 \mathrm{k} \quad$ (median CER of 385 sampled trees); low vitality, CER $>10.5 \mathrm{k}$. The vigour of the same fir was categorized by CSI: high vigour, CSI $=1-4$; low vigour, CSI $=5-7$. Trees were then classified according to combined ratings of vigour and vitality. Class A trees had high vitality and high vigour and were expected to be healthy, productive trees. Class $\mathrm{C}$ trees had low vitality and low vigour and were expected to be unhealthy, slowly growing trees. The intermediate class B trees were subdivided as B1 with high vitality and low vigour and B2 with low vitality and high vigour. Class B trees were expected to be of uncertain health and intermediate in productivity. The mean $\mathrm{RW}_{1989}$ was used to compare the productivity of the four classes.

To estimate the CER of previous years, six trees were selected at random from Class A and six from Class $C$ trees in 1990 and stem sections taken for dendrochronological analysis. Ring widths were measured using standard dendrochronological methods. The historical CER was estimated for the mean ring width series of the Class A and Class C trees using the linear regression model developed from CER measurements and $\mathrm{RW}_{1989}$. The estimated CER values were used to compare Class $A$ and Class $C$ fir before and after forest decline was observed in Slovenia.

Standard dendrochronological methods were also applied to an additional sample of seven Class $\mathrm{A}$ and seven Class $\mathrm{C}$ fir to determine the distribution of missing and incomplete rings in the most recent 20 years of growth. Growth rings were examined at $0.3,1.3$ and $10.0 \mathrm{~m}$ above the ground.

\subsection{Influence of NCP on CER}

Non-conducting phloem (NCP) of silver fir varied two- to three-fold in thickness (Fig. 1B). The effect of NCP thickness on CER was tested using bark wedges sawn from trees selected at random from each of Class A and Class C. Wedges were cut such that the wood and vascular cambium occupied the wide base of the wedge. Immediately after removal, the CER electrode was inserted into the sloping face of the NCP and through the vascular cambial zone (VCZ) contained in the wedge. By changing the position of electrode insertion along the NCP slope, the thickness of NCP penetrated by the electrode could be precisely varied. Additional wedges were used to determine the effect of removal of the VCZ on the electrical resistance of the bark wedges. Wedges were cut from four representative trees from each of Class A and Class C fir. Electrical resistance measurements were made at an depth of 2, 4 and $6 \mathrm{~mm}$ in the NCP with or without the attached VCZ. The effect on CER of tree class, NCP thickness, and the presence or absence of VCZ was tested by analysis of variance. Treatment means were compared using the protected least signficant difference $(\mathrm{p}<0.05)$. 
Table 3. Number of missing and incomplete growth rings for the previous 20 years in mature silver fir related to tree vitality and stem height

\begin{tabular}{|c|c|c|c|c|}
\hline \multirow[b]{2}{*}{ Tree class ${ }^{1}$} & \multicolumn{4}{|c|}{ Mean number of missing and incomplete rings at different stem heights ${ }^{2}$} \\
\hline & $0.3 \mathrm{~m}$ & $1.3 \mathrm{~m}$ & $10.0 \mathrm{~m}$ & $20.0 \mathrm{~m}$ \\
\hline Class A & 0 & 0 & 0 & 0 \\
\hline Class C & $8.6 \mathrm{a}$ & $7.1 \mathrm{ab}$ & $5.3 \mathrm{~b}$ & $2.1 \mathrm{c}$ \\
\hline \multicolumn{5}{|c|}{$\begin{array}{l}{ }^{1} \text { Class } \mathrm{A} \text {, high vitality and high vigour fir }(\mathrm{CER}<10.5 \mathrm{k}, \text { CSI } 1-4) \text {; Class } \mathrm{C} \text {, low vitality and low } \\
\text { vigour fir }(\mathrm{CER}>10.5 \mathrm{k}, \text { CSI } 5-7) \text {. } \\
{ }^{2} \text { Mean of seven observations taken at the tree base }(0.3 \mathrm{~m}) ; \text { breast height, }(1.3 \mathrm{~m}) \text {; mid-bole }(10 \mathrm{~m}) \text {; } \\
\text { and crown }(20 \mathrm{~m}) \text {. Least significant difference }(\mathrm{p}<0.05)=2.9 \text { rings. Different letters indicate that } \\
\text { the mean number of rings differs significantly with stem height }(\mathrm{p}<0.05) \text {. }\end{array}$} \\
\hline
\end{tabular}
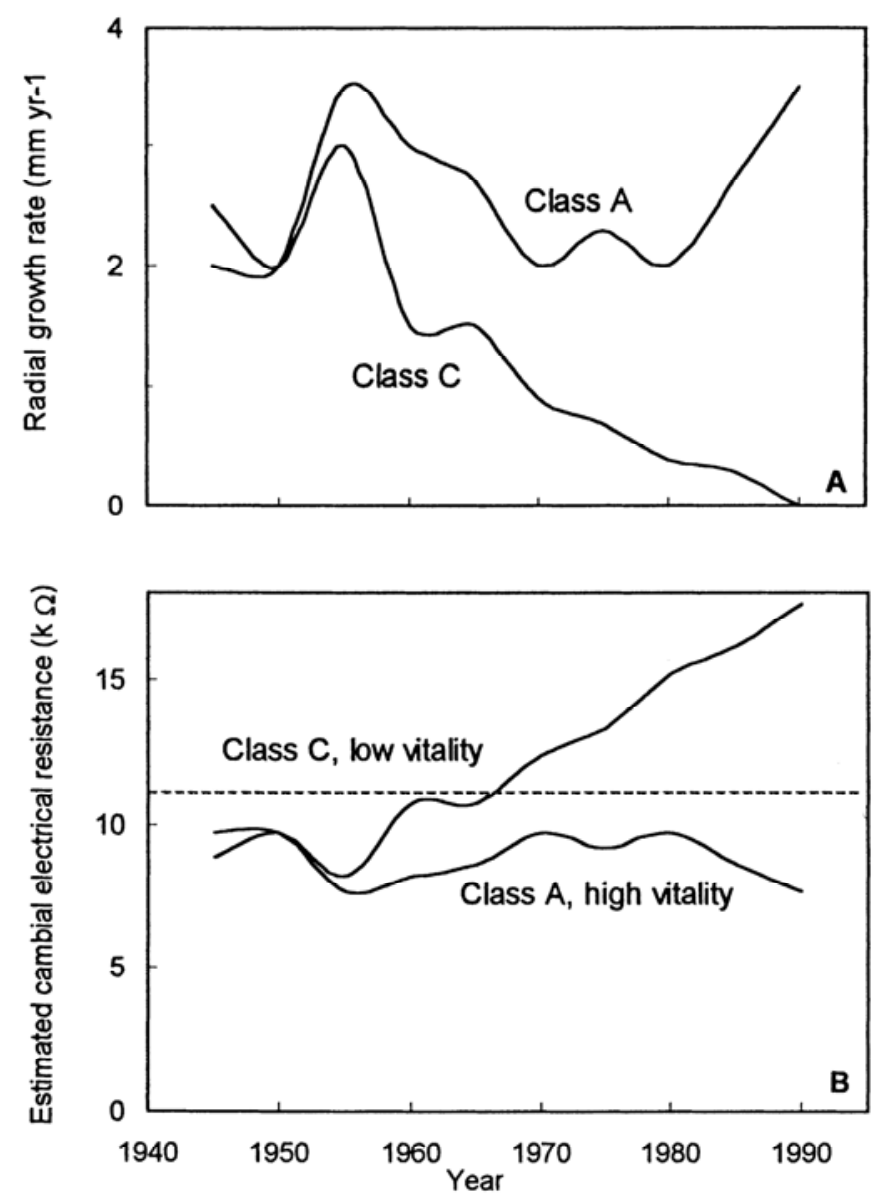

Fig. 2. A: smoothed ring widths for class A (high vigour, high vitality) and class $\mathrm{C}$ (low vigour, low vitality) silver fir. B: corresponding changes in estimated CER. The median CER of $10.5 \mathrm{k}$ is marked with a dashed line

likely to detect both the temporary decrease in growth between 1955 and 1970 and the following period of accelerated growth for Class A fir (Fig. 2A,B).

The CER values of Class A fir were signficantly less than those of Class $\mathrm{C}$ fir at all 
thicknesses of NCP that were tested (Table 4). As with intact trees, the CER of bark wedges with $6 \mathrm{~mm}$ of NCP was below the median CER (10.5 k ) for Class A trees and above the median CER for Class C trees. Removal of the VCZ resulted in increased CER, irrespective of tree class and NCP thickness. As fir declined due to external stresses, the vascular cambium ceased to form wood in a continuous layer around the perimeter and up the stem to the crown (Table 3). Wood formation essentially stopped in trees in advanced stages of disease and with low vitality and vigour.

\section{Discussion}

Both the crown status index (CSI) and the cambial electrical resistance (CER) were significantly correlated to ring width (Table 1). The CER has the advantage of being objective and easy to measure and record. Trees with visibly dying crowns were forming very little wood (Fig. 2, Class C), or none at all (Table 3). Suppression of stem growth (Table 2, Classes B1 and B2) was four times more common in fir with high vigour crowns (B2) than for fir with low vigour crowns (B1). This difference in the frequency of growth suppression between vigour classes suggests that the dying of crowns was not the primary path from high vitality Class A trees to low vigour and low vitality Class $C$ trees. This is consistent with a pattern of chronic below-ground stress described for dying silver fir resulting from chronic nutrient imbalances brought about by acid deposition (HARTig 1897; Tomlinson 1990). Although the cause of dying crowns may occur directly by needle damage or indirectly due to changes in soil and fine roots (BAUCH 1986), the observed patterns were more consistent with belowground stress.

Historic changes in ring width over several decades (Fig. 2A) are likely to have been detectable as changes in CER (Fig. 2B) prior to the development of visible symptoms in the crown. This early detection of growth suppression related to chronic below-ground stress (a 'bottom up' disease) would be of great value to the forest manager. Changes in CER would be equally valuable for detecting onset of growth suppression following acute foliar damage (a 'top-down' disease).

Variation in CER for Class $\mathrm{C}$ diseased fir was due primarily to variations in the thickness of NCP (Table 4), which was related to variations in periderm formation (Fig. 1B). Variation in CER in Class A fir was due primarily to differences in thickness of the vascular cambial

Table 4. Electrical resistance of nonconducting phloem, with (NCP + VCZ) and without (NCP) the adjacent vascular cambial zone (VCZ) from healthy, high vitality trees (Class A) and diseased, low vitality trees (Class $\mathrm{C}$ )

\begin{tabular}{|c|c|c|c|c|}
\hline \multirow[b]{3}{*}{ Electrode penetration, $\mathrm{mm}$} & \multicolumn{4}{|c|}{ Electrical resistance, $\mathrm{k}{ }^{1}$} \\
\hline & \multicolumn{2}{|c|}{ Class A trees } & \multicolumn{2}{|c|}{ Class $\mathrm{C}$ trees } \\
\hline & $\mathrm{NCP}+\mathrm{VCZ}$ & $\mathrm{NCP}$ & $\mathrm{NCP}+\mathrm{VCZ}$ & NCP \\
\hline 6 & $9.2 \mathrm{a}$ & $13.7 \mathrm{~b}$ & $13.0 \mathrm{~b}$ & $16.8 \mathrm{c}$ \\
\hline 4 & $10.5 \mathrm{a}$ & $17.5 \mathrm{~b}$ & $15.0 \mathrm{~b}$ & $21.5 \mathrm{c}$ \\
\hline 2 & $13.7 \mathrm{a}$ & $24.0 \mathrm{~b}$ & $21.5 \mathrm{~b}$ & $29.3 \mathrm{c}$ \\
\hline \multicolumn{5}{|c|}{$\begin{array}{l}{ }^{1} \text { Mean of four observations, } \operatorname{LSD}(\mathrm{p}<0.05) \text { for } 6 \mathrm{~mm} \text { insertion into bark wedge }=1.56 \mathrm{k} ; \text { for } 4 \mathrm{~mm} \\
\text { insertion into bark wedge }=3.47 \mathrm{k} ; \text { for } 2 \mathrm{~mm} \text { insertion into bark wedge }=6.30 \mathrm{k} \text {. Different letters } \\
\text { indicate that the mean ER values differ significantly at different depths of electrode penetration. }\end{array}$} \\
\hline
\end{tabular}


zone (SMITH et al. 1984), but the NCP (Table 3) could affect the strength of the relationship of CER to PGR (Table 1).

In dying silver fir trees with accelerated defoliation, the sapwood is not transformed into normal heartwood. Rather, the sapwood becomes intensively dehydrated, parenchyma cells die, and wet-wood forms (Torelli et al. 1986; Cufar 1990). In trees of low vitality with dying crowns, internal infections by wood decay pathogens and associated microorganisms can spread to and kill the vascular cambial region and reduce wood quality (Fig. 1A).

Electrical measurement techniques, combined with traditional forestry techniques, can assist forest management (Filip et al. 1992; LindBerg and JoHANsson 1989). Cambial electrical resistance measurements may be used in addition to visual symptoms to evaluate changes in tree stem vitality and wood-forming capacity. Additional measurements of internal electrical resistance to detect the incidence of infection may further aid in risk assessment (SHIGO and SHORTLE 1985). By selectively harvesting low-vitality fir that are beginning to show symptoms, the residual trees may be relieved of stress and become more vital and productive.

\section{Acknowledgements}

We thank the US Department of Agriculture, Office of International Cooperation and Development, Research and Scientific Exchange Division, and the US Department of Agriculture, Forest Service, Global Change Research Program and Ministry of Science and Technology of the Republic of Slovenia for providing financial assistance which made possible this joint research effort. We are also indebted to Dusan Robic, Martin Zupanicic, Primoz Oven, Peter Cunder, Bojana Krizaj, and Tom LevANIC for their help in the field and laboratory.

\section{Résumé}

\section{Détection de changements dans la santé et dans la productivité du sapin en Slovénie}

La résistance électrique du cambium (CER) a été utilisée comme mesure objective de la vitalité du sapin (Abies alba) dans les forêts de Slovénie. La CER des arbres a été mesurée pendant la saison de végétation et l'état des houppiers a été évalué (crown status index: CSI). La CER et le CSI étaient tous deux inversement corrélés avec l'accroissement annuel des cernes. En utilisant la CER et le CSI, les sapins ont été classés dans différentes catégories de vigueur. Les inférences faites à partir de ces catégories et les tendances de la croissance radiale, ont indiqué que la largeur des cernes avait diminué avant l'apparition des symptômes de houppiers. Cette diminution aurait pu être détectée par l'augmentation de la CER. Ce type de développement correspond à un dépérissement provoqué par un stress souterrain chronique. Le cambium vasculaire et l'épaisseur du phloème non conducteur étaient à l'origine des variations de la CER.

\section{Zusammenfassung}

Nachweis von Veränderungen im Gesundheitszustand und in der Produktivität bei Weisstannen in Slowenien

Die Vitalität von Weisstannen (Abies alba) wurde in den Wäldern Sloweniens mit Hilfe der Messung des elektrischen Widerstandes des Kambiums (CER) objektiv erfasst. An den Bäumen wurden während der Wachstumsperiode sowohl der CER als auch der - subjektiv erfasste - Kronenzustand (CSI) aufgenommen. Beide Parameter waren mit dem Radialzuwachs negativ korreliert. Anhand von CER und CSI wurden die Tannen verschiedenen 'Vitalitätsklassen' zugeordnet. Aus dem Vergleich dieser Kategorien mit den Trends beim radialen Zuwachs wird gefolgert, dass der Zuwachs bereits vor der Entwicklung von Kronensymptomen nachgelassen hatte. Dieser Zuwachsrückgang hätte als Zunahme des CER erkannt werden können. Dieses Muster im Krankheitsverlauf ist typisch für das Absterben von Bäumen infolge von chronischem Stress im Wurzelbereich. Die Variation des elektrischen Kambiumwiderstandes wurde sowohl durch das Kambium als auch durch die Dicke des nicht leitenden Phloems bestimmt. 


\section{References}

BAUCH, J., 1986: Characteristics and response of wood in declining trees from forests affected by pollution. IAWA Bull. N.S. 7, 269-276.

BeCKer, M.; Bert, G. D.; LandmanN, G.; Levy, G.; Rameau, J. C.; Ulrich, E., 1995: Growth and decline symptoms of silver fir and Norway spruce in northeastern France: relation to climate, nutrition, and silviculture. In: Forest Decline and Atmospheric Deposition: Effects in the French Mountains. Ed. by LANDMAnN, G.; BonNEAU, M. Berlin: Springer. pp. 120-142.

BlANCHARD, R. O.; SHORTLE, W. C.; DAVIS, W., 1983: Mechanism relating cambial electrical resistance to periodic growth rate of balsam fir. Can. J. For. Res. 13, 472-480.

BOSSHARD, W., 1986: Kronenbilder mit Nadel- und Blattverlustprozenten. Eidgenössische Anstalt für das forstlich Versuchswesen. Birmensdorf, 98 pp.

CUFAR, K., 1990: Electrical resistance of tissues, increment characteristics and response to injuries in healthy and diseased silver firs. Dissertation. University of Ljubljana, Slovenia. 167 pp.

DAvis, W.; ShorTle, W.; SHIgo, A., 1980: Potential hazard rating system for fir stands infected with budworm using cambial electrical resistance. Can. J. For. Res. 10, 541-544.

FILIP, G. M.; WiCKMAN, B. E.; MASON, R. R., 1992: Thinning and nitrogen fertilization in a grand fir stand infested with western spruce budworm. For. Sci. 38, 265-274.

HARTIG, R., 1897: Über den Einfluß des Hütten- und Steinkohlenrauches auf den Zuwachs der Nadelholzbäume. Forstlich Naturwissenschaftliche Z. 6, 49-60.

LEVANIC, T., 1997: Growth depression of the silver fir (Abies alba Mill.) in the Dinaric phytogeographic region between 1960 and 1995. Res. Reports For. Wood Sci. Technol. 52, 137-164.

LindberG, M.; JohAnSSON, M., 1989: The use of electrical resistance of cambium and phloem as a measure of tree vigor. Scand. J. For. Res. 4, 175-185.

Ostrofsky, W. D.; ShorTle, W. C., 1989: Application of the Shigometer for assessing tree and forest health and wood product quality - a review. Rev. Trop. Plant Pathol. 6, 39-57.

Oven, P., 1993: The anatomy of the bark and its response to mechanical wounding of healthy and affected silver firs (Abies alba Mill.). MS thesis. University of Ljubljana, Slovenia. $150 \mathrm{pp}$.

-; Torelli, N.; ZupANCIC, M., 1995: Anatomy of cambial zone and living bark as related to electrical resistance readings in healthy and affected silver fir (Abies alba Mill.). Acta Pharm. 45, 375-377.

SAF, 1958: Forest terminology: A glossary of technical terms used in forestry. Washington, DC: Society of American Foresters. 97 pp.

Shigo, A. L.; Shortle, W. C., 1985: Shigometry: a reference guide. Agriculture Handbook 646. Washington, DC: US Department of Agriculture. 48 pp.

ShORTLE, W. C., 1985: Electrical methods for evaluating growth and decay potentials of fir/spruce sites. In: Spruce-fir Management and Spruce Budworm. Gen. Tech. Rep. NE-99. Ed. by SCHMITT, D. Broomall, PA: US Department of Agriculture, Forest Service, Northeastern Forest Experiment Station. pp. 99-103.

-; BAUCH, J., 1986: Wood characteristics of Abies balsamea in the New England states compared to Abies alba from sites in Europe with decline problems. IAWA Bull. N.S. 7, 375-387.

-; Abusamra, J.; LAing, F. M.; Morselli, M. F., 1979: Electrical resistance method as a guide to thinning sugar maples. Can. J. For. Res. 9, 436-437.

-; SHIGO, A. L.; BERRY, P.; ABUSAMRA, J., 1977: Electrical resistance in tree cambium zone: relationship to rate of growth and wound closure. For. Sci. 23, 326-329.

Smith, K. T.; Blanchard, R. O.; SHORTLE, W. C., 1984: Cambial electrical resistance related to the number of vascular cambial cells in balsam fir. Can. J. For. Res. 14, 950-952.

SOlAR, M., 1986: Air pollution and forest decline in Slovenia. In: Proceedings of the 18th IUFRO World Congress, Div. 2, Vol. 1, Forest Plants and Forest Protection. Vienna, Austria: Secretariat International Union of Forestry Research Organizations. pp. 368-380.

Tomlinson, G. H. (ed.), 1990: Effects of Acid Deposition on the Forests of Europe and North America. Boca Raton, FL: CRC Press. 281 pp.

Torelli, N.; CufAR, K.; RobiC, D., 1986: Some wood anatomical, physiological and silvicultural aspects of silver fir dieback in Slovenia (NW Yugoslavia). IAWA Bull. N.S. 7, 343-350. 